MedieKultur | Journal of media and communication research | ISSN 1901-9726

Article

\title{
Climate-conscious citizenship in a digital urban setting
}

\section{Sophie Esmann Andersen \& Anne Ellerup Nielsen}

\author{
MedieKultur 2011, 50, 119-142
}

Published by SMID | Society of Media researchers In Denmark | www.smid.dk The online version of this text can be found open access at www.mediekultur.dk

Climate change has challenged urban life, and as an omnipresent force, Nature sets the agenda for urban living. Using stakeholder theory to conceptualise urban life, we approach Nature as both an omnipresent stakeholder and an issue to be continuously addressed and related to. Adapting the stakeholder focus to relations, stakes and values, we conceptually analyse the digital installation entitled CO2mmitment/ CO2nfessions, which was a prominent part of the Aarhus CO2030 exhibition launching the vision of the Danish city of Aarhus to become carbon neutral by the year 2030. In the analysis, we explore how the citizen is framed and invited to enact his/her responsibilities to the natural environment in an urban setting and how the digital mediation facilitates various forms of relations and climate conscious positions, incorporating both narcissistic desires, universal anxiety, moral obligations, ethical virtue and image performance. Statements from the actual confessors/committers exemplify this. Thus, the paper provides insight into understanding the complexity of climate-conscious citizenship as a complex configuration of paradoxical, co-existing ethics and arguments. 


\section{Introduction}

The environment and the climate have increasingly been placed on political, economic, governmental and cultural agendas as primary priorities. Corporations are encountering demands with regard to social responsibility and sustainable productivity, consumers are increasingly facing up to the issue of climate-conscious behaviour, and politicians are being met with demands regarding environmental priority (Stohl et al., 2007; Carroll, 2008). Recently, the climate has correspondingly been placed on city agendas, and cities, municipalities and counties around the world are creating measurements for sustainability, e.g., by outlining goals for carbon neutrality. In other words, a new actor has entered urban life: nature. And as an omnipresent force, she sets the agenda for urban life as well as for how to conceptualise urban living. Nature has become a premise of urban life, replacing local, geographical borders with global challenges (Andersen \& Nielsen, 2009).

The municipality of Aarhus has initiated a campaign entitled Aarhus CO2030, expressing a vision of becoming carbon neutral by the year 2030 . The campaign was launched at a fourday exhibition encouraging citizens to interactively engage in the climate debate. One of the main features of the exhibition was the installation entitled CO2nfessions/CO2mmitment: an advanced video installation, inviting citizens to confess their climate sins and commit to future sustainable behaviour while at the same time broadcasting the confessions and commitments onto screens placed throughout the city. The installation thus expressed creative, innovative and provocative ways of engaging citizens. The purpose of this paper is to conceptually analyse how the installation CO2mmitment/CO2nfession frames and invites citizens to reflect and act upon their co-responsibilities with regard to climate change challenges. Framed within the concept of stakeholder, focusing on stakeholders as the very notion of relations and relationship building, we analyse how the CO2mmitment/CO2nfession initiates different positions of climate conscious citizenship. Following this, we argue that climate conscious citizenship can be conceptualised as a complex configuration of paradoxical, co-existing ethics and motifs, as it positions narcissistic desires, universal anxiety, moral obligations, ethical virtue and image performance as well as ironic distancing and plain indifference.

\section{Theoretical framework}

\section{Stakeholder theory}

Organisational and stakeholder management theory deals with the way organisations are conceptualised and managed, defining organisations in terms of groupings of stakeholders with the purpose of managing stakeholder interests, needs and attitudes (Friedman \& Miles, 2006). Since the mid-1980s, the stakeholder concept has gained ground. According to one of the fathers of stakeholder theory, Robert E. Freeman, stakeholders are defined as "groups and individuals who can affect, or are affected by the achievement of an organisation's mission" (Freeman, 1984). Stakeholder management has grown in popularity not 
only in academic circles but also among policymakers, regulators, NGOs, businesses and the media. Stakeholder management is closely related to Corporate Social Responsibility (CSR) in the sense that CSR initiatives lead to company-favouring evaluations from stakeholders and to enhanced relationships between a company and its stakeholders (Maignan et al., 2005; Bhattacharya et al., 2009). Referring to the social commitment of businesses in society, CSR has expanded considerably in the 1990s and 2000s (Crane et al., 2008). Businesses now have an obligation towards their stakeholders, and in recent years their engagement with multiple stakeholder groups has resulted in a variety of global voluntary corporate citizen initiatives such as nongovernmental public action, civil activism, public/private partnerships etc. (McIntosh, 2007, p. 46). Corporate citizenship emphasises the social and societal aspect of CSR and concerns how corporations understand and manage their wider influences on society, both for their own and for the benefit of society (Marsden \& Andriof, 1998). As part of a political-economic agenda about corporations' self-interests, rights and obligations in society (Crane \& Matten, 2007, p. 168), corporate citizenship encompasses ethics, philanthropy, stakeholder management, as well as social and environmental responsibilities (Mirvis \& Googins, 2006, p. 107). Corporations are seen as powerful local inter-actors who have obligations to and benefit from strategic stakeholder relationships in exchange for providing work and capital in a societal context. Stakeholder concern and how to create value for stakeholders are thus considered important issues not only in private businesses but also in all types of organisations, including public policy institutions such as cities and municipalities. Philosophically speaking, stakeholding represents a general sense of social inclusion in a community in which every stakeholder is a valued member who contributes and benefits. From a participatory perspective, stakeholding assumes active participation in processes of accountability; and financially speaking, a material interest in the well-being of an enterprise legitimates such participation (Clarke, 1997, p. 211).

The stakeholder approach to doing business has not only contributed to redefining private businesses, from a closed shareholder oriented perspective to organisations as open, fluid and dynamic unities for which networking and relationship building with local and global stakeholder are crucial and part of co-creative value creation (Hatch \& Schultz, 2010) Stakeholder thinking has also gained terrain in public sector institutions where relationship building and partnerships are equally important due to the increasing practice of collaborative networks and partnerships between public and private institutions (Nielsen \& Thomsen, 2011). As a model for conceptually grasping urban living, Andersen and Nielsen (2009) adapt a stakeholder approach, demonstrating how the stakeholder concept redefines urban life as it replaces the classical notion of geographical boarders and public power structures with a complex web of stakes and stakeholder relations. What becomes interesting when entering city life are relations and the issues addressed and legitimised, as well as the values derived from these relationships. The concept of stakeholders is thus not only interesting as a theoretical framework, but also as analytical lenses to conceptualise cities and agendas therein. Furthermore, as the notion of stakeholders has developed into 
a co-creative, dynamic and inter-related concept, it is not only interesting from an organisational perspective. It is also constructive as an analytical frame for approaching individual stakeholders, focusing on how individuals enter diverse relations when faced with global challenges, which they both affect and are affected by, for example when it comes to the climate change challenge. In this case, nature sets the agenda.

\section{Nature as a stakeholder}

According to the traditional conceptualisation of stakeholders, non-human beings cannot be part of a stakeholder group. From this perspective "nature" is excluded as a stakeholder, as the natural environment supplies resources to organisations but usually not through economic exchange relationships (Driscoll \& Starik, 2004, p. 58). However, since the natural environment holds coercive and utilitarian power over businesses and industries as an important part of the business environment (through super-storms, hurricanes and more recently global climate change), there is no reason why the role of stakeholder should not include non-human phenomena such as nature (Starik, 1995, p. 209).

From this perspective, stakeholder relations become legitimised by something larger than both organisational and individual values, thereby overruling the classical stakeholder approach in which organisations constitute the centre of power. Introducing nature as an integrated (and dominating) part of the stakeholder map, ethics is the new agenda forcing both individuals and organisations to legitimise their own position in the stakeholder network by addressing "nature" as an omnipresent stakeholder.

The idea of "nature" as an important inter-player who adapts different meanings according to specific contexts and relations, is also approached from an anthropological perspective. Anthropologist Mary Douglas (1996) describes four distinct cultures that have distinct myths about nature. Nature is framed as "unpredictable", "robust", "robust within limits" or "fragile" according to particular cultural groups and their life circumstances. However, based on pre-established cultural categories, this approach does not take into account the flexibility of recent and non-centric stakeholder conceptualisations in which stakeholders may jump in an out of different relationship with nature according to their particular agendas, roles and relationships. From this perspective, nature is constantly negotiated and legitimised according to the meanings and values derived from and ascribed to either the citizen/nature relationship or the relationships between citizens and the role of nature in such relationships. In other words, we adopt a dynamic relational approach to nature as a persistent stakeholder affecting urban living.

\section{The city as a stakeholder enterprise}

Adapting a stakeholder approach to cities and urban living is not groundbreaking. On the contrary, during the nineties, marketing and management seem to have taken on a profound role within the public sector and urban studies. Research in urban studies shows that 
a conceptualisation of cities and places as centric unities within geographical boundaries is disappearing and being replaced by an understanding of cities as socially constructed, non-contiguous, diverse, dynamic and superimposed networks of social relations and understandings (Graham \& Healey, 1999). Public administration and urban governance incorporate stakeholder management and disciplines such as branding (e.g., Virgo \& de Chernatony, 2006), corporate communication (e.g., Trueman et al., 2004), and marketing (Kotler et al., 1993), initiated by the Public Management Reform (Pollitt \& Bouckaert, 2000) in which the public sector is ascribed a market-oriented behaviour. Hence, we are witnessing what is known as a management and marketisation of society at large and of the public sector and state-owned enterprises in particular - at both the organisational and individual level. Corporations are conceptualised as citizens (and corporate citizens, Crane et al., 2004), and individuals are addressed as consumer citizens (cf. Littler, 2009; Ritzer, 2008). Both within research and as a social practice, there has been a blurring of boundaries between the public and the market, staging the city as a marketised enterprise, involving complex organisational structures and mechanisms. Thus, the application of theories of management and organisation to public administration and urban research seems reasonable and is not new: Virgo and de Chernatorny base their city brand-building model on the premise of multiple and complex variety of stakeholders, arguing that city branding "involves complexities beyond those of product and service branding" (Virgo \& de Chernatorny, 2006: 379). Trueman et al. (2004) take a similar approach by combining city branding and stakeholder management, as they point out conflicting objectives of stakeholder groups as a basic reason for a complex brand structure dealing with multiple identities. Stakeholder groups are complex in the sense that there are no distinct and natural borderlines between individuals as consumers, citizens, employees, on the one hand, and organisations composed of individuals as employees, partners, suppliers, customers etc., on the other hand (Gabriel \& Lang, 2006). This multiple and relational identity approach is particularly noticeable in a citizen context, where the identity of the city as a living organisation overlaps with its citizens as inhabitants, taxpayers, corporations/institutions, consumers etc. (Andersen \& Nielsen, 2009).

Following the notion and arguments of the marketised city and based on a stakeholder approach, we frame the city as a space for configurations of stakeholder relations to emerge and dissolve with the appearance and disappearance of specific issues and agendas, e.g., the global climate change challenge. To frame the city within a stakeholder perspective makes the city appear in the form of relational networks and patterns of manifest and latent stakes and interests (Andersen \& Nielsen, 2009). Conceptualising the city as a stakeholder enterprise generates an awareness of which agendas and relations are at stake - and an awareness of values derived from and ascribed to these relationships. With the instantiation of nature as a pivotal point and persistent stakeholder, citizens must continuously legitimise their role in relation to the natural environment: nature is an overarching condition and point of reference as well as an omnipresent condition. And consequently, nature cannot not be 
addressed. From a climate change perspective, citizens must continuously legitimise their own climate-conscious (or climate-polluting) behaviours. From a municipal perspective, all citizens have a shared responsibility, whether as consumer-citizens, corporate-citizens or other members. Nature is a persistent condition of the city to be continuously addressed by its citizens according to their constantly shifting identities and relationships. This coresponsibility is highlighted in Aarhus CO2030, expressing the vision of Aarhus to become CO2-neutral by 2030: all citizens must take responsibility to effectuate the vision. However, before examining the case of Aarhus CO2030, we review consumer responsibility and the socially responsible consumer-citizen, which is specifically addressed in the CO2fession/ CO2mitment installation in order to establish the premise for approaching climate conscious citizenship as carrying meaning beyond its virtuous value.

\section{The socially responsible consumer-citizen}

Traditionally conceptualised, a citizen is a person who is member of a state with associated rights and obligations. The concept of citizen is, thus, foundational to one's national and political identity (Gabriel \& Lang, 2006, p. 173). However, according to Gabriel and Lang (2006), the traditional conception of the citizen loses ground along with the marketisation of society and the triumph of consumerism. Increasingly, citizenship is framed from the perspective of consumption practises (Ewan, 1992), blurring the boundaries between consumers and citizens; terms such as "consumer-citizen" and "political consumerism" encapsulate this notion. From an environmental perspective, this is accentuated by an increased interest in how consumer actions leave carbon footprints and, correspondingly, on ways of reducing these consumer conquests of the ecological space (van Brakel \& Buitenkamp, in Grabriel \& Lang, 2006). Thus, social responsibility and climate conscious behaviour is instituted as an inherent part of consumer-citizen obligation. On the one hand, we are witnessing increased consumer-citizen pressures on both corporations and politicians to take on social responsibility, and on the other hand, increased pressure has been put on the consumer-citizen to adopt responsible consumption actions. In other words, we see devolution of responsibility among all stakeholders.

This manifests a more general interest in consumer social responsibility (Caruana \& Crane, 2008; Obermiller et al., 2009; Williams, 2005). Caruana and Crane (2008) examine the role of corporations in constructing the nature, meaning and implications of "consumer responsibility" and suggest that corporations through their corporate communication instantiate consumer responsibility as a shift in the locus of choice from whether to consume, to which way to consume. And they conclude, that "[r]esponsibility then is not just something that consumers have (in whatever quantity), but is a cultural mythology that consumers can draw on and derive meaning from" (Caruana \& Crane, 2008, p.1514). The work of Caruana and Crane (2008) marks a shift of interest from quantitative aspects of consumer behaviour towards an interest in qualitative dimensions of consumer responsibil- 
ity: it is not about segmenting green consumerism and modelling different shades of green consumers (e.g., Mostafa, 2009), but rather a question of conceptualising consumer responsibility as a process of sense making. It is not about forcing responsible behaviour through scare campaigns (Spoel et al., 2009) or public control of citizen behaviour (D'Souza, 2004), but rather a question of understanding why consumers act responsibly in order to (and as a way to) add meaning in their lives, drawing on an interpretive tradition of consumer research (Østergaard \& Jantzen, 2000).

Moisander and Pesonen (2002) have explored this interpretive research path of consumer responsibility and ethical consumption as a way of living, exploring the constructing of selves and others as green consumers. They argue that green consumption is discursively constituted by the practices of self rather than by consumption as such, drawing attention to the self-reflexive aspects of green consumer choices (Moisander \& Pesonen, 2002). Following this notion, Haanpää (2007) constructs green consumerism as indications of a postmodern lifestyle and argues that green consumption decisions can be understood as striving for a green lifestyle, which is stable only in terms of a set of consumption styles (Haanpää, 2007, p. 484). In other words, ethical consumption and responsible consumer behaviour is a complex affair, a point which is also supported by Szmigin et al. (2009), who highlights the relevance of flexibility and dissonance theory in order to approach the conscious consumer and what they address as the "competing priorities, paradoxical outcomes, and the nature of compromises reached in real decision processes" (Szmigin et al., 2009, p. 224).

It is exactly these paradoxes and complexities that motivate this study as we analyse the CO2nfessions/CO2mmitment installation in order to explore and conceptualise how consumers are invited to engage in climate conscious citizenship. Below, we introduce the CO2nfessions/CO2mmitment installation followed by an outline of the analytical framework derived from the concept of stakeholder and applied to the context of climate conscious consumer-citizenship. On this basis, we analyse different positions of climate conscious consumer-citizenships promoted by the CO2nfessions/CO2mmitment installation, which are illustrated and exemplified by consumer-citizen quotes from the CO2nfessions/CO2mmitment box. Subsequently, the paper discusses the different climate conscious positions with regard to relational structure and perception of nature, followed by concluding remarks and suggestions for future research.

\section{CO2nfession/CO2mmitment in an urban setting}

As a response to persistent climate change challenges and with reference to the hosting of the COP15: United Nations Climate Change Conference in Copenhagen, Denmark, December 2009, several Danish cities are endeavouring to become CO2 neutral within a relatively short period of time. ${ }^{2}$ The municipality of Aarhus has initiated a campaign entitled Aarhus CO2030, expressing a vision of becoming carbon neutral by the year $2030 .^{3}$ The Aarhus 
CO2030 initiative was launched at a four-day exhibition (March 2009) in downtown Aarhus and invited corporate- and consumer-citizens to interactively engage in the climate debate. The exhibition is an exemplary illustration of a collaborative and participatory approach to social responsibility and the inclusion and engagement of the entire stakeholder network in complying with climate change challenges. In order to meet global challenges, local actions are required, whether by individuals, corporations or governments. Thus, the exhibition consisted of both corporate initiatives on sustainable innovations, sustainable designs by educational and research institutions, political speeches, public debates, presence of environmental organisations, aesthetic and artistic sound and vision installations as well as displays of consumer related sustainable products and services.

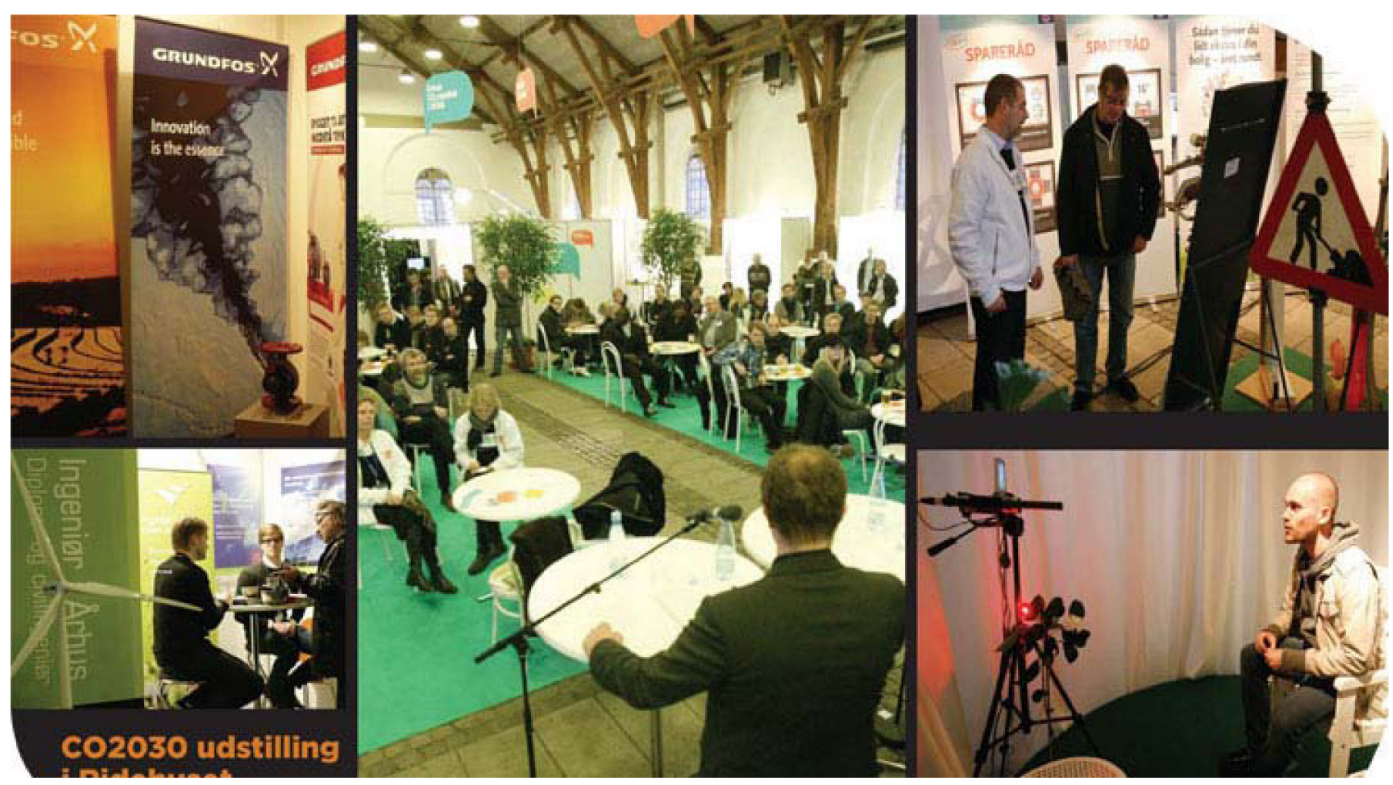

Picture 1: Pictures from the four-day exhibition, launching the Aarhus CO2030 initiative taken by Martin Brynskov and Rune Nielsen

One of the main features of the exhibition was the installation entitled CO2nfessions/ CO2mmitment: an advanced video installation that gives a face to the struggle for climate improvements and gives the citizens of Aarhus a voice to be heard - and seen - throughout the city (cf. www.co2030.dk).

As part of the $\mathrm{CO} 2$ agenda, $\mathrm{CO} 2$ nfession/CO2mmitment is a technologically innovative and creative platform. In short, the installation features a compartment or cubicle where individuals (and small groups) are invited to "confess" their climate sins and "commit" to future climate-responsible behaviour in front of a digital camera recording the confessions and displaying them on digital screens placed throughout the city. 

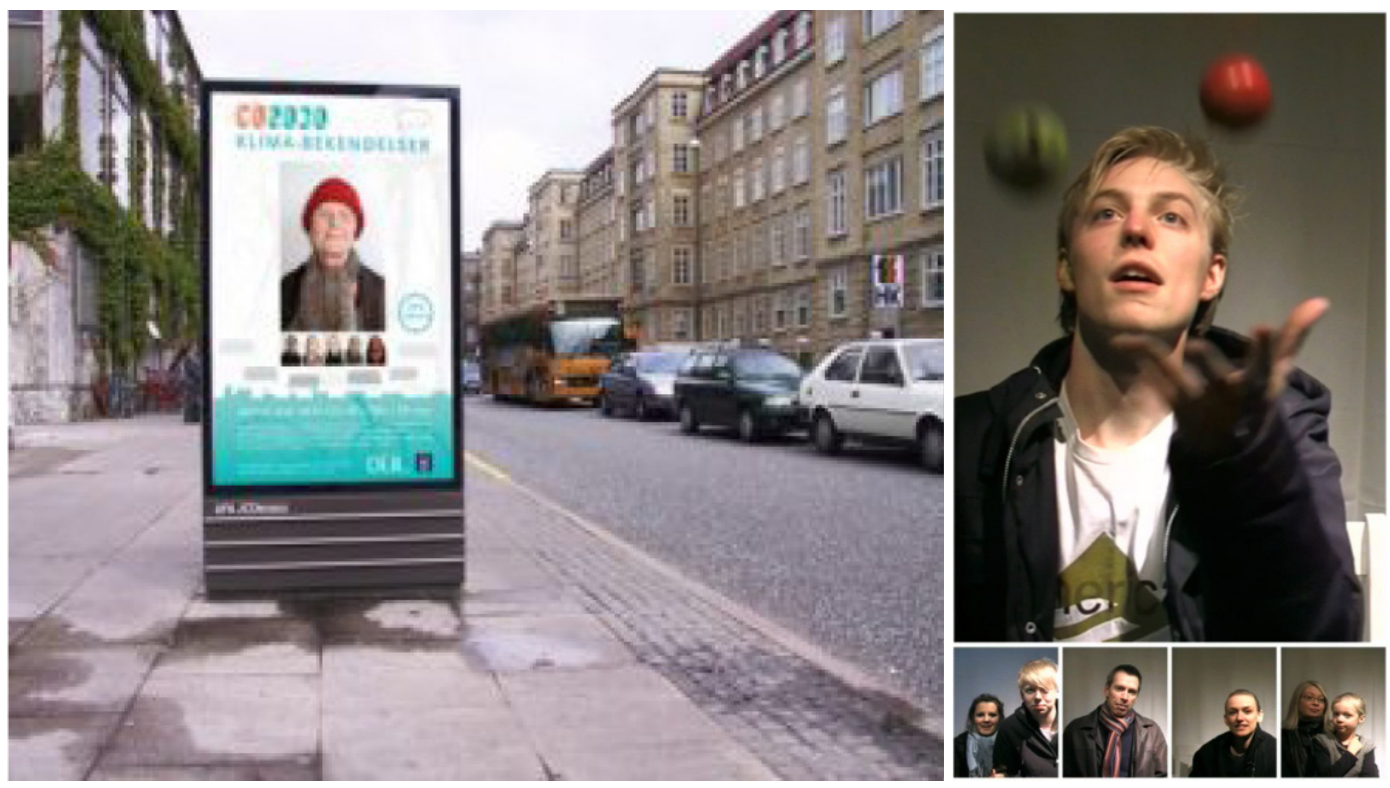

Picture 2: Pictures from the CO2nfession/CO2mmitment installation taken by Martin Brynskov and Rune Nielsen

CO2nfession/CO2mmitment is of analytical interest for several reasons. First, it addresses climate change as a topical issue, installing nature as an urgent stakeholder (Andrioff et al., 2002). Second, the installation offers a refreshing and revitalising element in the climate debate; by introducing new technologies it brings the climate debate into urban living and literally onto the streets of urban life. By virtue of its technological and digital form, providing new modes of communication, the installation is interesting in itself: it engages citizens, and in terms of content it is driven and generated solely by its ability to engage citizens in dialogue through participation and creativity. Without citizen engagement, the installation is nothing but empty screens. And finally, in terms of data collection, the installation both generates and stores empirical data, convenient for research. These elements make the CO2nfession/CO2mmitment installation particularly interesting and likely to provide insight into the framing of climate conscious citizenship.

\section{Analytical framework}

The premise for approaching the case is drawn from the interpretive research path of consumer responsibility and ethical consumption as stated above, arguing that responsible actions carry meaning other than the actions themselves, i.e., climate conscious behaviours are not solely motivated by the behaviours in and of themselves, but also carry and entail emotional and symbolic values. Drawing on the notion of stakeholders as the analytical lens for approaching CO2nfession/CO2mmitment, we argue that these emotional and symbolic values are created through the establishing of real or imaginary relationships. The 
framework thus constructs an analytical focus on stakeholder representations and derived conceptualisations of the citizen (i.e., who does the citizen relate to in his confessions/commitments and what characterises these relationships?). In continuation of this, the framework builds a focus on the different meanings that nature (as an omnipresent stakeholder) can be ascribed according to its role within the different relationship.

Summarising, the framework constructs the following analytical dimensions:

- Stakeholder representations, identifying real or imagined relations constructed by the confessor/committer

- The different types of relationships and their ontology

- Conceptions of the consumer-citizen in the diverse relational settings

- Conceptions of the climate/nature in the diverse relational settings

- Meanings of the climate conscious actions within the relationships

- Spatial dialectics, which explore the different configurative meanings of the relations between the private intimacy and the public scenery.

On this basis, the following provides a conceptual analysis of the CO2nfession/CO2mmitment installation, which is illustrated by examples of and quotes from the actual confessions/ commitments videotaped during the climate exposition March 5-8, 2009. Methodologically speaking, the paper follows a deductive mode of reasoning in which on the basis of theoretical constructs we establish analytical lenses and key words as a framework for analysing the case. Accordingly, the empirical data take on an illustrative and exemplary position in order to qualitatively enrich the discussions. The paper could have chosen a more grounded approach (e.g., Glaser, 1998) to the actual empirical confessions and commitments. However, the data stored did not (either quantitatively or qualitatively) provide enough depth or rich insights to analytically stand alone, meaning that even though the installation was open for confessions, only a relatively small number of citizens actually entered the box to confess/commit. Quantitatively speaking, the data totalled approx. one hour of video streaming, containing statements ranging from 10 seconds to approx. three minutes and including several repeaters. Qualitatively speaking, the video streaming ranges from children giggling to the camera to rich and unfolded confessions/commitments; and from people voluntarily entering the box to people being incited and allured to enter, including technical comments from the designers of the installation. Thus, only a relatively small part of the video streaming contains actual comments on climate conscious actions. However, the installation is also of conceptual interest, as argued above, as the very concept thematises new ways of handling responsibility towards climate change, instantiated by the mediation of the private in the public and the intermediation between the public and the private (and its derived configurations). On this basis, the analysis takes its point of departure from a conceptual perspective. 


\section{Conceptualising climate-conscious positions}

The CO2nfession/CO2mmitment installation incorporates a classical religious discourse and stages the Catholic scenario of confession and absolution, relating non-climate-conscious citizenship to a metaphorical complex of confessing sins and forgiveness. However, as a mediated construction, the event dissolves the original intimacy and confidentiality existing between priest and confessor in the classical universe of absolution, as the camera and mediation transform an intimate relationship into a public setting. Following this, the CO2nfession/CO2mmitment installation establishes double-sided spaces for engaging in the climate change agenda caused by the tension between the intimate and public space, which manifests itself into a range of dialectic spatial configurations: mental/physical, lived/performed, local/global, present/future, constantly playing with, challenging and confronting our perception of what is real and what is staged; what is lived and what is mediated. The installation thus provides spaces for the citizens to navigate and formulate this co-responsibility entering different positions of climate conscious citizenship. Analytically, we extrapolate five positions, which are unfolded and exemplified below. Subsequently, the positions are discussed and summarised in table 1.

\section{A cosmic quest of anticipating doomsday}

As a concept, and drawing on the classical notion of confessionals, the CO2nfession/CO2mmitment installation thematises the relation between past and present sins and future behaviours. Literally speaking, the confession box occupies a here-and-now space for reflecting on one's sins in order to get absolution and adopt better future behaviours. This spatial dialectic between the past, present and future is reflected as climate change is placed on the agenda and nature is at stake: religious undertones are resituated in a cosmic game, in which the individual citizen is accountable to nature.

Following this, the citizen faces a cosmic responsibility towards the natural environment - or in more abstract terms, towards nature as an all-encompassing future. Consequently, responsibility is not posed in terms of a free initiative to prevent disasters, but rather as a responsibility imposed on the citizen universally. Within a cosmic rhetoric of climate-conscious citizenship, the CO2nfession/CO2mmitment installation becomes a metonym of the classical confession box in which the confessor confesses to something larger than life; but it replaces God with nature, with the authority and power to give absolution, and it replaces the eyes and ears of the Catholic priest with a camera as a symbolic channel to nature. Driven by a quest of anticipating doomsday, climate-conscious citizenship is a matter between the individual and nature: personal and present responsibilities are assigned in relation to cosmic future alliances, and individual actions are linked to cosmic consequences. Thus, climate conscious action takes on a submissive character and becomes a question of providing for future generations by avoiding the destruction of the planet through the abuse of its resources. Within this cosmic relationship, the citizen can be conceptualised as an anxious citizen (anxious about facing world doom due to the overcon- 
sumption of natural resources, and anxious about leaving an excessive carbon footprint, for instance), and citizens have a responsibility to protect the natural environment against any such misconduct. Thus, when driven by a quest of anticipating doomsday, climateconscious citizenship is about taking initiatives to prevent disasters, and it represents concrete initiatives that citizens take, promise to take or fail to take with the aim of rescuing the planet. Apparently small and insignificant everyday actions (such as riding a bike instead of taking a car, keeping the city clean, recycling garbage etc.) are situated within a frame of catastrophes, fear and end of the world, thereby creating an image of the citizen as someone who anticipates a perilous future. Responsibility is conceptualised as an absolute necessity if future generations are to survive. Hence, the citizen is held responsible for his actions not to other humans, but to the planet. This anticipation of doomsday is explicitly articulated by a group of children who enter the box in order to perform what they call an advert for the CO2030 campaign. By using flower bowls with brightly coloured flowers, images of a cow and a happy-faced garden gnome, they set the scene for a future scenario where farmers breed happy cows and cultivate fertile soil. However, the scene is abruptly and aggressively torn apart, followed by the claim "if the climate disappears, the cows will die", generating a future worst-case scenario as a potential consequence of present actions.

\section{A licence to live}

The CO2nfession/CO2mmitment box can take on a political lens framing the confessing/ committing citizen as a member of a community, i.e., the city. In confessing their climate sins, citizens thus approach climate conscious behaviour by drawing on their citizenship. From this perspective, climate conscious behaviour is instantiated as the good citizenship it takes to gain a "licence to live" in the city. Having rights (social benefits such as social aid, voting at local elections, having access to public schools etc.) and obligations (work, paying taxes etc.), citizens are to balance and exchange social responsibility with their community (nation or a city as in our case). They are bound by a political and juridical agenda to form relationships in the city, turning the city into a local space of interaction for communal issues to be planned, managed and changed according to stakeholder citizens' needs and expectations. Good climate citizenship thus creates a particular community relation between the citizen and his fellow citizens to whom he relates and uses as social, cultural, economic and/or geographic models of identification or distinction. This type of community inclusion is explicitly addressed by a male confessor who positions the climate change challenge from a political perspective and enters the CO2nfession/CO2mmitment box as an engaged political speaker, inscribing his own climate-conscious actions into a communal "we", e.g.: "Here in Aarhus, we must become better at reducing CO2 emission". The community approach also appears as a request to enter more imaginative relations. A young man utters: "I will help the climate by making a difference at a political level. That is what I will personally do, and I hope you will do the same". The invitation is open to join the community of good citizenship practice. 
What the citizen confesses displayed between the local and global space of the city is his willingness to stabilise and balance his "licence to live" as an obliged citizen against his "investment" in nature as a resource of fair distribution. The mediation of the confessor's relationship to nature from a civic perspective is the act of confessing with the aim of gaining legitimacy. This is not from a pastoral authority or supremacy, but in the eyes of and with support of his fellow citizens manifested as an imaginative community, it is also concrete in the camera of the CO2nfession/CO2mmitment box. Fellow citizens are the ones to give absolution, which is emphasised in the public transmission of the citizen's confession of good or bad civic practices. Thus, the symbolism of the mediation takes on a literal meaning. When the voice and face of the confessor is transmitted from a local into the public space, it is because the voice is of public interest: the confession becomes an act of both local public and global public speaking. More specifically, the mediation transforms the meaning of the act of confession in its extrapolation between the local geographic towards the global reach of the city space. Installing the global climate agenda of the city as localised and yet articulated as a glocal manifestation, the confession of the citizen as the obliged citizen becomes an imitation of a prototypical world summit political speaker's corner. This is articulated by confessors' frequent reference to what they "ought to" and "should" change by complying with an established code of mainstream climate rules, such as turning off standby electricity, reducing warm baths, using energy saving bulbs and alternative energy sources etc. Several confessors support this reasoning by confessing that what they do is "not good enough" (compared to a non-expressed and generally accepted rule), and that from a rule-based (Kantian) perspective, they should act differently. This rhetorical framing may also take on a virtuous character (cf. below). A chemical engineer in the confession box demonstrating the high amount of $\mathrm{CO} 2$ emission that the opening of a bottle of soda releases, advises his fellow citizens to get biofuel operating cars in order to reduce $\mathrm{CO} 2$ emission, stating at the end of his confession: "remember this". Expressed as an imperative, his voice gains an instructive status. Following this notion, the confessional becomes a learning environment: a new way of socializing fellow citizens into a moral community.

\section{A desire for image performance}

While the legitimizing position frames the individual within a discourse of political citizenship drawing on the intermediary between local/global responsibilities, this position refers to a discourse of consumerism and performance cultures. From a perspective of legitimacy, CO2nfession/CO2mmitment offers not only a way of seeing (and learning) how to act responsibly by imitating fellow citizens and hence legitimising responsible citizenship, but also a way of being seen, per se. Responsible behaviour becomes a way of being seen by others. From a positioning perspective, relations are established and performed to an audience, who share the same basic assumptions regarding responsible behaviour and who recognise and acknowledge the behaviours as responsible. And what defines the relationship between the individual and his/her target audience is expressive in character: good 
deeds become self-praising, a show off. Hence, climate-conscious actions take on an aesthetic character, as they are performed in order to stage oneself towards a real or imaginary community of shared beliefs; a way of drawing attention to and positioning oneself. Reducing the household level of $\mathrm{CO} 2$ and buying organic groceries are not just practised as civic obligations, but add an ethical dimension to one's image. The climate (and nature) becomes a commodity for the performing and self-expressive citizen. Altered into a stage for image performance, the CO2nfession/CO2mmitment installation transforms the intimacy and inner dimension of the confessional context into expressivity and exterior relations: the camera symbolises the market occupied by fellow consumers in relation to whom the individual constantly stages his good deeds with the purpose of being recognised and acknowledged as a citizen with a good, responsible appearance. The stake at stake is one's image. Following this, potentially genuine goodness and spontaneous climate conscious actions transform into strategic quests of image performance: it is not about being good or doing good, but about looking good from an ethical point of view.

This position is difficult to ignore (as will also be discussed later) due to the installation's very concept of digital mediation and broadcasting of statements into public space, which to a great extent is in itself an invitation to stage oneself. And in several statements, the very concept of image performance overshadows the climate issue; people enter the box without having anything to say and driven solely by the prospect of being the main character in an urban narrative about nothing but performance, they sing, dance, giggle and disconnect from the climate issue. Consequently, there is a blurring of boundaries between an audience and the camera per se; it is all about the notion of performing. This is stressed in a dialogue between a man and a woman inside the CO2nfession/CO2mmitment box. The man says that they better end their conversation, to which the woman replies: "But it so nice, that people are listening." The man answers that nobody is listening. To this, the woman states: "The camera does." This articulation could refer to the very notion of being given a voice in the climate debate, thus being addressed as an important co-player and where the camera symbolises a classical speaker's corner. However, the dialogue could also be interpreted as a meta-comment on the performance in itself, inscribing it into a performative context rather than a context of politics and social responsibility. This perspective of positioning is supported by the following example, where a middle-aged woman expresses visions for her own future behaviour: "I will ride my bike to work. Actually I already do that, but I will keep on doing it. And I have thought about dancing with my husband instead of turning up the heat. And let the dance keep me warm." What is interesting here is not only the content of the statement in which she links the more abstract notion of climate conscious behaviour to an intimate relationship, turning the caring for nature into a question of nurturing new intimate relationship, but also the very form in which the statement is delivered. It seems as if the delivery of the message (i.e., the act of confessing) is more important than (or of equal importance as) the act of climate conscious behaviour, which is stressed as the woman reads her statements from a manuscript: the scene is set, now the act must be staged cor- 
rectly. Several confessors support this theatre metaphor as they bring diverse artefacts (or props) into the CO2nfession/CO2mmitment box (cf. the children performing an advert for the CO2030-campaign using flower bowls etc., a male bringing a lemon, a boy bringing a fishing pole etc.).

\section{Constructing climate conscious selves}

The above-mentioned position of expressing and exhibiting good deeds positions the consumer-citizen within a frame of external image performance, whereas the present position is rooted in the notion of internal self-reflection. As the classical confessional, the CO2nfession/CO2mmitment box is a space for transformation: a space for reflection and identity constructions. Not in the image of God, but in the image of good deeds, i.e. climate conscious actions. This transformative process is reflected in the following quote: "I confess. I have been the climate-idiot. And I don't want to be him anymore." Here, the confessor addresses a transformation from one self to another. He illustrates the transformation by showing a lemon, onto which he has drawn a grumpy face on one side, symbolising the "climate idiot", and a happy face on the other, symbolising the future self who he wishes to become: a self who acts accordingly to the agenda of climate change challenges.

Following this idea, it is not about obeying God, but about creating oneself reflexively, transforming good deeds into a self-developing quest. From a conceptual perspective, the intimate, reflexive space (physically manifested within the borders of the confession box) is ascribed a bodily representation through the digital mediation. Literally speaking, the installation provides not only a voice to be heard, but also a face to be seen in an urban space. In other words a double-sided space for both mental reflection and bodily investment is constructed, in which the individual can narrate and negotiate possible selves. A young male explicitly brings out this physical embodiment, stating: "I turn my back on $\mathrm{CO}_{2}$. And I do it now" [followed by the man physically turning his back to the camera]. The body physically captures the here-and-now space and literally becomes his actions, which is concretised by his mooning to the camera.

The duality between reflexion and bodily investment is very present in the actual empirical confessions, which offer several examples of users not being aware that the camera is recording (the camera records non-stop and does not need to be activated as assumed by many users). This misconception results in the creation of what might be termed a quiet, almost contemplative space for self-reflection, in which the citizen is mentally "charged" before broadcasting and which becomes an opposition to the mediated space, in which the body is brought into play. In other words, what is at stake is a bodily articulation of the dialectic between the mental and physical space, which is discursively manifested in the oftenrepeated question: "Am I on" [translation: "Er jeg på?"] and diverse statements in which the inner thoughtfulness is superseded by an external bodily awareness.

In this type of framing, the citizen can be conceptualised as a self-reflexive citizen, constantly striving to uphold a coherent narrative of the self, translating climate conscious 
actions into a narcissistic quest of creating oneself in the image of good actions. Climateconscious behaviour becomes a self-reflexive process arguing that the individual constructs his self-identity based on good deeds. For instance, when the individual conserves energy as a consumption activity, he is able to construct himself as a caring, responsible and ethical consumer. Nature becomes an extension of the self; a resource for providing meaning and coherence for one's self-identity. Following this somewhat narcissistic understanding of climate-conscious citizenship, the CO2nfession/CO2mmitment box is transformed into a mental space for self-reflection and self-negotiation, driven by a desire to create a meaningful and coherent narrative of the self based on responsible behaviour. The installation provides a mental space for the individual to negotiate his own self, played out as an emotional relation between the individual citizen and the camera, symbolising the individual's own climate conscience. The camera becomes a mirror to reflect one's own deeds, transforming the act of confessing into an inner dialogue about who I am and who I want to be. The confessions give voice to these inner dialogues and to what might be termed as negotiations between different self-narratives: narratives drawing on hedonistic consumption and indulgence versus self-narratives built on responsible behaviours. For instance, a young woman in the CO2nfession/CO2mittment box states: "I think I am quite good at keeping electronic devices on standby. And I am very good at un-plugging the cell phone charger" and she keeps listing all these energy consuming activities within a discursive frame of positivity, creating a positive self-narrative concerning her present lifestyle This does not immediately harmonise with an environmentally conscious self-story as she later states: "Unfortunately, I fly a lot which is quite CO2 polluting, so I could be better if I did not travel that much. But I don't feel like not doing this." She seems here to articulate a dilemma between possible selves: an explorative, vivacious, hedonistic and well-travelled self versus a climate conscious self, in which the latter is rejected. A young male articulates a similar however more pronounced struggle between possible selves, stating: "I love electricity [translated from: "Jeg elsker strøm"]. All kinds of electricity: My computer, my TV, my radio, my warm cup of coffee. All kinds of electricity. Lights. Electricity is so cool. And I will try to cut down, but it is going to be difficult and I know I will be sad, very sad".

This quote demonstrates how climate conscious behaviour conflicts with his way of living and his self-story, emphasising a personal transformation from love to sadness, thus creating an emotional bond to nature as a resource of the self-narrative; however a sad nonindulgent story.

However, the transformation from one to another is not necessarily a problematic affair, as one young boy enters the box carrying a fishing pole stating: "Instead of eating red meat, I would rather catch my own fish and it tastes better". The boy constructs a future scenario of responsible actions making climate change a positive starting point for exploring new adventures: a catalyst for an active and playful lifestyle which he expectantly subscribes to, thus creating a framework for the future and for the ideal self to live out. 
Summarising, this position adapts a narcissistic perspective to climate conscious actions, thus creating the citizen as a self-reflexive citizen striving to construct a responsible selfnarrative in the image of responsible behaviours, and in which nature is conceptualised as a potential resource for constructing these self-narratives. Nature becomes an integrated part of the future "me", which is ironically reflected upon by a young woman, who in a ridiculing meditative state is trying to transform into a tree, obtaining $\mathrm{CO}_{2}$ instead of emitting $\mathrm{CO}_{2}$. This ironic distancing plays an interesting part in analytically extrapolating the virtuous dimension of climate conscious actions, in which responsibility is framed as a universal ethic. This position will be elaborated below.

\section{The ethical urge to do good}

While the representation of climate confessions above position the citizen in relation to external or internal concerns and issues, the CO2nfession/CO2mittment box also becomes a generator of "rightness" for many of the confessors demonstrating that they take for granted the pre-existence of a default climate behaviour ideal which is simply better and purer than others and which accordingly needs no further justification. This type of assumption is frequently manifest when confessing citizens either reason against this ideal position of good climate behaviour by implicitly referring to a hidden topos for what is the best and most virtuous climate behaviour, or they ironically exaggerate good behaviour by overplaying their climate conscious role. Following this framing, the citizen becomes a "good citizen" displayed in a universal space, where present, future, proximity and distance are dissolved and replaced by an virtuous universe where right and wrong is never negotiated and good deeds are never questioned.

Conceptualized as good by doing good deeds, the good citizen is "good" per se: a citizen for whom the act of confessing is sincere and spontaneous in that it collapses with the act of doing good, eroding the act of absolution. Consequently, when entering the CO2nfession/CO2mittment box, the good citizen takes on a strategic and disruptive character in the sense that reduced to the pure climate conscious action in and for itself, the good citizen is related to nobody and to the entire universe at the same time. Posed in a universal space, and relating to the climate conscious action as such, the good citizen engages in an ethical relationship with nature, anthropomorphised (Starik, 1996) as an omnipresent individual to relate to and care for at all times. The ethical relationship established by the citizen as the "good citizen" and his climate conscious actions do not need any detours through performance, staging or positioning of the self. Neither does it call for rules or codes of ethics in order to survive; it only takes the climate conscious actions themselves to be virtuous actions. In this positioning, the good citizen is beyond mediation. In the confession box the socially responsible behaviour is articulated with implicit reference to the above-mentioned universally pre-established, unquestionable but also unattainable ideal: climate consciously per se, i.e., in all respects at all times is to play the acme to climate by deselecting, e.g., air transport, gasoline driven cars, long hot showers etc., as an unreflective and unintentional 
gesture. Nevertheless, because of the clash with the mediated form and consequently the meaninglessness of confessing deeds that are never bad but only good, this supreme ethical position is never explicitly articulated in the confession box. The camera implodes, losing its function as mirror, performer, stager etc. The following quote of a young male is an example of the indirect manifestation of how the virtuous actions and inherent social responsibility of the "good citizen" are articulated: "I usually have my computer and my TV set turned on, and I know that I ought to unplug electronic devices, while I don't use them". Here, the confessor narrates himself in the image of an ideal climate conscious person, whom he either strives for becoming, but cannot become, or distances himself from becoming. This reference is also activated by a citizen who, after listing all the good deeds he does (living in an eco-community, investing in wind energy, driving an electric car etc.), confesses that he is also the owner of a diesel driven car for which he apologises. The apology for behaving as he does supports the idea that in the eyes of the virtuous representative of this unarticulated ideal he ought to become a better citizen. Finally, the framing of the good citizen may take a different shape based on a discourse of exaggeration. A citizen dressed as a bank robber with a scarf half covering his face ironically argues for using his bike instead of a car to transport stolen items, because of the lower price of transportation, throwing a cost benefit logic perspective into the climate agenda. The point here is that the extrapolation of this ironic approach to climate conscious positioning demonstrates to what extent the citizens distance themselves from the socially responsible citizen in its purest form, posed as an unrealistic response to climate change or as a supra-natural ideal that we may all dream of becoming, but will never live up to. The logic of a universal ethic as an ideal frame of reference thus seems to be redefined as actual behaviours in the name of an ethic of pragmatism.

\section{Discussion and concluding remarks}

Based on a conceptual analysis of the digital installation CO2mmitment/CO2nfession as part of the municipality of Aarhus' campaign CO2030 and framed within a relational perspective, this paper has extrapolated five positions from which citizens differently engage in, reflect and act upon their co-responsibilities with regard to climate change challenges. The paper initially built an analytical framework on the basis of stakeholder theory and the notion of symbolic consumption practise, encompassing six analytical foci: a) stakeholder representations, b) types of stakeholder relations, c) conceptions of the consumer-citizen, d) conceptions of the climate, e) the meanings of the climate conscious actions and finally f) spatial dialectics. These analytical dimensions have guided the conceptual analysis of the CO2mmitment/CO2nfession box and are summarised in the table below: 
Article: Climate-conscious citizenship in a digital urban setting

\begin{tabular}{|c|c|c|c|c|c|}
\hline $\begin{array}{c}\text { Spatial } \\
\text { dialectics }\end{array}$ & $\begin{array}{c}\text { Stakeholder } \\
\text { representa- } \\
\text { tions }\end{array}$ & $\begin{array}{c}\text { The citizen } \\
\text { conceptualised } \\
\text { as }\end{array}$ & $\begin{array}{c}\text { Nature } \\
\text { conceptualised } \\
\text { as }\end{array}$ & $\begin{array}{c}\text { Ontology of } \\
\text { the relation- } \\
\text { ship }\end{array}$ & $\begin{array}{c}\text { Climate } \\
\text { Conscious } \\
\text { Actions }\end{array}$ \\
\hline Present/future & $\begin{array}{c}\text { The natural } \\
\text { environment }\end{array}$ & $\begin{array}{c}\text { The anxious } \\
\text { citizen }\end{array}$ & $\begin{array}{c}\text { A resource of } \\
\text { life }\end{array}$ & Cosmic & Submissive \\
\hline Local/global & $\begin{array}{c}\text { Society and } \\
\text { fellow citizens }\end{array}$ & $\begin{array}{c}\text { The obliged } \\
\text { citizen }\end{array}$ & $\begin{array}{c}\text { A resource of } \\
\text { fair distribution }\end{array}$ & $\begin{array}{c}\text { Political/ } \\
\text { juridical }\end{array}$ & Legitimising \\
\hline performed & $\begin{array}{c}\text { The market } \\
\text { and its actors } \\
\text { physical }\end{array}$ & $\begin{array}{c}\text { The good- } \\
\text { looking citizen }\end{array}$ & A commodity & Expressive & Aesthetic \\
\hline Oniversal & $\begin{array}{c}\text { The climate } \\
\text { conscious } \\
\text { action as such }\end{array}$ & $\begin{array}{c}\text { The self- } \\
\text { reflexive citizen }\end{array}$ & $\begin{array}{c}\text { An 'extended' } \\
\text { self/a resource } \\
\text { of self-narrative }\end{array}$ & Emotional & Narcissistic \\
\hline
\end{tabular}

Table 1: Conceptualising climate-conscious citizenship

The table summarises the way in which the articulation and conceptualisations of nature and citizens respectively, by taking the five positions construct different forms of relations and appoint different stakeholders. Framed within a paradigm of anxiety, the citizen conceives nature as an omnipresent resource that gives and takes lives, an entity with which the citizen is forced to contract a relation in order to prevent doomsday. This type of relationship is submissive, and is created in the image of the anxious citizen: action is inevitable for survival.

However, the citizen may also contract relations to society and fellow citizens in order to legitimise his/her role in society by proving that he/she is a good fellow citizen, obtaining a "licence to live". From this perspective, nature is conceived as a resource of fair distribution by which the role of being a good citizen is negotiated in order to balance the account of legitimacy.

From the perspective of image performance, climate-conscious citizenship is not about being good, but about looking good, whereby nature becomes a commodity and an important prop in staging and managing a socially responsible image. Consequently, socially responsible actions become part of a self-staging project rather than acting out the citizen's responsible obligation. The action becomes secondary to the expression and appearance of the action itself, placing the citizen in focus and turning climate change into an event that facilitates the objectification of nature.

Citizens may also engage in climate-conscious behaviour for more narcissistic and affective reasons - a position in which the citizen constructs his own identity based on socially responsible actions, adding a self-reflexive dimension to behaving in a socially responsible manner. The citizen is thus conceptualised as a reflexive self, constantly striving to construct 
and maintain a coherent narrative of the self. And nature is seen as a resource of this process of construction. When carrying out climate-conscious behaviour, nature is conceived of as an extended part of the self, installing a self-reflexive relation: the citizen understands himself in the light of his own responsible actions, helping to create himself as a responsible individual. From this perspective, climate-conscious citizenship is internally driven.

The last position of climate-conscious behaviour is framed as a "pure" engagement, and reflects a notion of the citizen as an ethically committed citizen doing good because he cannot not do good! Within this frame, the citizen relates to an ethical justice and acts according to its normative prescription, simply because it is the only right thing to do. Climate-conscious behaviour in this respect is the goal itself, subscribing to Aristotle's notion of virtue ethics.

However, $\mathrm{CO} 2$ mmitment/CO2nfession challenges this Aristotelian notion of pure, universal ethics through its mediated dimension. We have analysed this as a dilemma as it states the digital mediation of socially responsible actions as a basic premise, raising the question of whether socially responsible actions can ever be conceived of as pure and sincere actions when communicated actively: can citizens communicate about their climate-conscious behaviour without such behaviour being ascribed to other intentions? The case of $\mathrm{CO} 2 \mathrm{~m}$ mitment/CO2nfessions pushes the dilemma to the extremes, as it converts the privacy and intimacy of absolution into a public experience. However, the analysis illustrates that the mediation is not just a mode of communication and a way of expression: it actively (or at least potentially) facilitates new modes of urban climate-conscious behaviour, actions and relationship building.

The five positions are not mutually exclusive of each other. On the contrary, and as the analysis demonstrates, the different positions are simultaneously present as positions to navigate between, compete against and compare one's own actions to. On this basis, climate-conscious citizenship is lived, challenged and staged as a complex configuration of paradoxical, co-existing ethics and arguments.

\section{Limitations and future research}

In this paper we have outlined potential positions for citizens to navigate in response to climate change within a digital setting and from a conceptual perspective, taking the point of departure in theoretical constructs of stakeholder relations. These relations are analysed with regards to type and conceptualisations of the involved participants, including nature. However, our paper does not address the quality of the established relationships. One might argue that the digital mediation prescribes experiences, citizen participation and engagement (e.g., Jenkins, 2006b) and helps strengthen the arguments for engaging in climate-conscious behaviour. However, one might also query the depth and quality of these relations: do they lead to behavioural change with a view to achieving the goal of carbon neutralisation of the city of Aarhus by the year 2030? In continuation of our analysis, it 
could be stated that the digital mediation adds a somewhat cynical and strategic element to climate-conscious behaviour, as ethical responsibility in a virtuous "good character" sense is replaced by strategic image management, forefronting image more than depth and substance, leading to an obsession with self-performance. From this perspective, one might query the long-term consequences of the constructed relationships: are they durable for framing future ethical actions, or are they simply superficial and inconsistent relationships worshipping the passion of the moment, the passion of self-worshipping and performance in public space? Our study provides a conceptual framework for future research to address these issues and hence explore the actual climate-conscious behaviour of citizens in everyday life.

\section{References}

Andrioff, J., Waddock, S., Husted, S. \& Sutherland Rahman, S. (2002). Unfolding Stakeholder Thinking. Theory, Responsibility and Engagement, Sheffield: Greenleaf.

Andersen, S.E. and Nielsen, A.E. (2009). The city at stake: 'stakeholder mapping' the city. Culture Unbound, 1, 305-329.

Arvidsson, A. (2008). The Ethical Economy of Customer Coproduction. Journal of Macromarketing, 28(4), 326-338.

Arvidsson, A. \& Peitersen, N. (2008). The Ethical Economy, retrieved April 15, 2010, from the Ethical Economy website: http://www.ethicaleconomy.com/files/EthicalEconomy_CH2.pdf.

Beauchamp, T.L. \& Bowie, N.E. (2001). Ethical Theory and Business (6th ed.). Upper Saddle River, NJ: Prentice-Hall.

Beckmann, S.C. (2006). Consumers' perceptions of and responses to CSR: So little is known so far. In M. Morsing \& S.C. Beckmann (Eds.), Strategic CSR Communication (pp. 163-183). Copenhagen: Djøf Publishing.

Bhattacharya, C.B., Sen, S. \& Korschun, D. (2009). Strengthening Stakeholder-Company Relationships Through Mutually Beneficial Corporate Social Responsibility Initiatives. Journal of Business Ethics, 85(2), 257-277.

Carroll, A.B. (2008). A history of corporate social responsibility - concepts and practices. In A. Crane, A. McWilliams, D. Matten, J. Moon \& D.S. Siegel (Eds.), The Oxford Handbook of Corporate Social Responsibility (pp. 19-46) . Oxford University Press.

Caruana, R. \& Crane, A. (2008). Constructing Consumer Responsibility: Exploring the Role of Corporate Communication. Organization Studies, 29, 1495-1519.

Clarke, T. (1997). Measuring and managing stakeholder relations. Journal of Communication Management, 2(3), 211-221.

Crane, A. \& Matten, D. (2007). Business Ethics (2nd ed.). Oxford University Press.

Crane, A., McWilliams, A., Matten, D., Moon, J. \& Siegel, D.S. (2008). The Corporate Social Responsibility Agenda. In A. Crane, A. McWilliams, D. Matten, J. Moon \& D.S. Siegel (Eds) The Oxford Handbook of Corporate Social Responsibility (pp. 3-15). Oxford University Press.

Douglas, M. (1996). Thoughts of style. London: Sage Publications 
Driscoll, C. \& Starik, M. (2004). The primordial stakeholder: Advancing the conceptual consideration of the natural environment's stakeholder status. Journal of Business Ethics, 49(11), 55-73.

D'Souza, C. (2004). Ecolabel programmes: a stakeholder (consumer) perspective. Corporate Communication: An International Journal, 9(3), 179-188.

Du, S., Bhattacharya, C.B. \& Sen, S. (2010). Maximizing Business Returns to Corporate Social Responsibility (CSR): The Role of CSR Communication. International Journal of Management Reviews, 12, 8-19.

Ewan, S. (1992). From consumer to citizen. Intermedia, 20(3), 22-23.

Freeman, E. (1984). Strategic Management: A stakeholder approach. NY: Pitman.

Friedman, A.L. \& Miles, S. (2006). Stakeholders - theory and practice. Oxford University Press.

Gabriel, Y. \& Lang, T. (2006). The Unmanageable Consumer. London: Sage.

Giddens, A. (1991). Modernity and Self-Identity: Self and Society in the Late Modern Age. Stanford University Press.

Glaser, B.G. (1998). Doing Grounded Theory: Issues and Discussions. California: Sociology Press.

Graham, S. \& Healey, P. (1999). Relational Concepts of Space and Place: Issues for Planning Theory and Practice. European Planning Studies, 7(5), 623-647.

Haanpää, L. (2007). Consumers' green commitment: indication of a postmodern lifestyle? International Journal of Consumer Studies, 31, 478-486.

Harrison, R., Newholm, T. \& Shaw, D. (2005). The Ethical Consumer. London: Sage.

Hatch, M.J. \& Schultz, M. (2010). Towards a theory of brand co-creation with implications for brand governance. Journal of Brand Management, 17(8), 590-604.

Jenkins, H. (2006). Fans, Bloggers, and Gamers. New York \& London: New York University Press.

Kotler, P., Haider, D.H. \& Rein, I. (1993). Marketing Places. NY: The Free Press.

Leong, T.W. \& Brynskov, M. (2009), 'CO2nfession: engaging with values through urban conversations', Proceedings of the 21st Annual Conference of the Australian Computer-Human Interaction.

Lewis, T. (2008). Transforming citizens? Green politics and ethical consumption on lifestyle television. Continuum. Journal of Media \& Cultural Studies, 22(2), 227-240.

Littler, J. (2009). Radical Consumption: Shopping for change in contemporary culture. Berkshire: McGraw Hill/ Open University Press.

Maignan, I., Ferrell, O.C. \& Ferrell, L. (2005). A Stakeholder Model for Implementing Social Responsibility in Marketing. European Journal of Marketing, 39(9/10), 956-977.

Marsden C. \& Andriof J. (1998), "Towards an Understanding of Corporate Citizenship and How to Influence It". Citizenship Studies, 2(2), 329-352.

McIntosh, M. (2007). Progressing from Corporate Social Responsibility to Brand Integrity. In S. May, G. Cheney \& J. Roper (Eds.), The Debate over Corporate Social Responsibility (pp. 45-58). Oxford University Press.

Melé, D. (2008). Integrating ethics into management. Journal of Business Ethics, 78(3), 291-297.

Mirvis, P. \& Googins, B. (2006). Stages of Corporate Citizenship. California Management Review, 48(2), $103-$ 126.

Moisander, J. \& Pesonen, S. (2002). Narratives of sustainable ways of living: constructing the self and the other as a green consumer. Management Decision, 40(4), 329-342.

Mostafa, M.M. (2009). Shades of green: A psychographic segmentation of the green consumer in Kuwait using self-organizing maps. Expert Systems with Applications, 36, 11030-11038.

Mueller, B. (2007). Just where does corporate responsibility end and consumer responsibility begin? The case of marketing food to kids around the globe. International Journal of Advertising, 26(4), 561-564.

Nielsen, A.E. \& Thomsen, C. (2011) "Sustainable development - the role of network communication". Corporate Social Responsibility and Environmental Management (in print). 
Obermiller, C., Burke, C., Talbott, E. \& Green, G.P. (2009). 'Taste Great or More Fulfilling': The Effect of Brand Reputation on Consumer Social Responsibility Advertising for Fair Trade Coffee. Corporate Reputation Reviews, 12(2), 159-176.

Pollitt, C. \& Bouckaert, G. (2000). Public Management Reform - a comparative analysis. Oxford University Press.

Ritzer, G. (2008). McDonaldization of Society. LA: Pine Forge Press.

Spoel, P., Goforth, D., Cheu, H. \& Pearson, D. (2009). Public Communication of Climate Change Science: Engaging Citizens Through Apocalyptic Narrative Explanation. Technical Communication Quarterly, 18(1), 49-81.

Starik, M. (1995). Should trees have managerial standing? Toward stakeholder status for non-human nature. Journal of Business Ethics, 14(3), 207-218.

Stohl, M., Stohl, C. \& Townsley, N.C. (2007). A new generation of global corporate social responsibility. In S. May, G. Cheney \& J. Roper (Eds.). The Debate over Corporate Social Responsibility (pp. 30-44). Oxford University Press.

Szmigin, I., Carrigan, M. \& McEachern, M.G. (2009). The conscious consumer: taking a flexible approach to ethical behaviour. International Journal of Consumer Studies, 33, 224-231.

Trueman, M., Klemm, M. \& Giroud, A. (2004). Can a City Communicate? Bradford as a corporate brand. Corporate Communications: An International Journal, 9(4), 317-330.

Virgo, B. \& de Chernatony, L. (2006). Delphic Brand Visioning to Align Stakeholder Buy-in to the City of Birmingham Brand. Brand Management, 13(6), 379-392.

Wilder, C. (1978). From the interactional view - A conversation with Paul Watzlawick. Journal of Communication, 28(4), 35-45.

Williams, A. (2005). Consumer Social Responsibility. Consumer Policy, 15(2), 34-35.

Østergaard, P. \& Jantzen, C. (2000). Shifting Perspectives in Consumer Research: from buyer behaviour to consumption studies. In S.C. Beckmann \& R.H. Elliott (Eds.), Interpretive Consumer Research (pp. 9-23), Copenhagen: Copenhagen Business School.

\section{Acknowledgements}

This research has been funded by the Danish Council for Strategic Research, 09-063245, (Digital Urban Living). We would like to thank the researchers affiliated Centre for Digital Urban Living and in particular Martin Brynskov, PhD, who was project manager at the CO2nfession/CO2mmitment-case. The

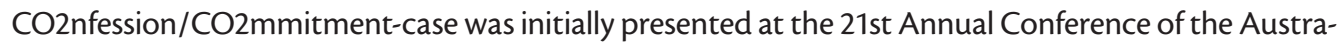
lian Computer-Human Interaction, 2009:

\section{Notes}

1. We do not see urban life as opposed to rural life, but merely as our analytical unit of study. The case used in this study explicitly address citizenship in an urban (digital) setting. Hence, we conceptualise urban life and urban citizenship not in opposition to global, national or regional citizenship, but as a manifest community to which citizens are locally related. Our case does not provide insights into global, national or regional levels of citizenship, for instance in relation to intercultural differences.

2. Internationally, cities such as Amsterdam, Vancouver and Sydney have expressed similar visions. And both internationally and nationally, we are witnessing competitions on becoming the first carbon neu- 
tral city/county/country. For instance, in the Middle East, in the landscapes of Abu Dhabi, the world's first carbon neutral city, Masdar, is being built, expected to home approx. 50,000 inhabitants.

3. Aarhus is the second largest city in Denmark with a population of more than 300,000 , and approximately 13 per cent of this population attends courses of higher or further education. This makes Aarhus the youngest city at heart in Denmark, which is reflected in a rich and varied cultural and business life, characterised by innovation and new thinking. For instance, Aarhus has the largest concentration of important media enterprises and higher education institutions in Denmark. These characteristics are communicatively embraced by the city's core brand value, which is "Pulse". In relation to climate, Aarhus has been made the Energy Town of 2009, by the Danish Ministry of Climate and Energy, thereby serving as an innovative frontrunner with regard to the climate. The city of Aarhus has previously taken initiatives and acted as a frontrunner in responding to climate and environmental challenges, e.g., by initiating public campaigns such as "Clean City".

4. We have translated the quotes used in the paper from Danish into English based on their default meaning in the context of climate change confession/commitment. For quotes containing unidiomatic or self-created words or expressions, we have inserted these fragments from the original data into the text.

Sophie Esmann Andersen, PhD Associate Professor Centre for Corporate Communication Centre for Digital Urban Living Aarhus School of Business and Social Science Aarhus University, Denmark sea@asb.dk

Anne Ellerup Nielsen, PhD Associate Professor Centre for Corporate Communication Centre for Digital Urban Living Aarhus School of Business and Social Science Aarhus University Denmark aen@asb.dk 